\title{
The Role of Urban Agriculture Approach in Food Supply and Export Ability (Case Study of Neishabour in Iran)
}

\section{El papel del enfoque de la agricultura urbana en el suministro de alimentos y la capacidad de exportación (estudio de caso de Neishabour en Irán)}

\author{
Mohammad Reza Mojtahedi
}

PhD student in Geography and Urban Planning, Islamic Azad University, Mashhad Branch, Iran ORCID: https://orcid.org/0000-0002-7600-1881

\section{Katayoun Alizadeh}

Department of Geography, Mashhad Branch, Islamic Azad University, Mashhad, Iran ORCID: https://orcid.org/0000-0001-7875-0977

\section{Hamid Jafari}

Department of Geography, Mashhad Branch, Islamic Azad University, Mashhad, Iran ORCID: https://orcid.org/0000-0002-2007-562X

Received 02-08-20 Revised 04-10-20

*Correspondence

Email: K-alizadeh@mshdiau.ac.ir
Cite as:

\footnotetext{
Mojtahedi, M., Alizadeh, K., \& Jafari, H. (2021). A The Role of Urban Agriculture Approach in Food Supply and Export Ability (Case Study of Neishabour in Iran). Propósitos y Representaciones, 9 (SPE1), e881. Doi: http://dx.doi.org/10.20511/pyr2021.v9nSPE1.881
} 


\section{Summary}

The growth of cities and the increase of urban population in recent years has caused many problems for the health of the environment and citizens. On the other hand, given that urbanism is inevitable, we must think of ways to reduce the pressure on nature by cities and improve economic and social indicators in cities. Urban agriculture will play an effective role in establishing a logical relationship between urban needs and improving the economic situation. In this research, the study of the role of urban agriculture from an economic point of view, especially in the field of food supply and export ability has been emphasized. The research method is descriptive-analytical and based on collecting survey data (field). The main research tool is a questionnaire. Its validity was confirmed by elites and its reliability was confirmed by completing 30 questionnaires through Cronbach's alpha at a level greater than 0.70. The study population was 264,375 citizens living in Neishabour. The sample size was determined by Cochran's formula equal to 384 people. The results showed that urban agriculture is significant in food supply and export ability at a level of less than 0.05 . The city's agriculture can be effective in improving the export of organic products, fruits and vegetables, exports of ornamental and medicinal plants, branding of products, as well as in supplying fresh vegetables, providing healthy food, improving the quality of nutrition and protein. Urban agriculture has a significant level of less than 0.05 in urban development indicators such as improving the urban environment, improving employment, improving citizens' incomes, creating attractive urban spaces, rainwater consumption, etc. From the people's point of view, it is possible to cultivate crops such as peaches, Damask rose, poultry breeding, etc., according to the available spaces. The study of the role of urban agriculture through structural equations shows that the total effect is 0.81 and in total urban agriculture can explain about $56 \%$ of the variance of role-playing and two variables of meeting food needs and export ability.

Keywords: urban agriculture, food, export ability, Neishabour city.

\section{Resumen}

El crecimiento de las ciudades y el aumento de la población urbana en los últimos años ha provocado muchos problemas para la salud del medio ambiente y de los ciudadanos. Por otro lado, dado que el urbanismo es inevitable, debemos pensar en formas de reducir la presión sobre la naturaleza por parte de las ciudades y mejorar los indicadores económicos y sociales en las ciudades. La agricultura urbana desempeñará un papel eficaz en el establecimiento de una relación lógica entre las necesidades urbanas y la mejora de la situación económica. En esta investigación se ha enfatizado el estudio del papel de la agricultura urbana desde un punto de vista económico, especialmente en el campo del suministro de alimentos y la capacidad exportadora. El método de investigación es descriptivo-analítico y se basa en la recopilación de datos de encuestas (campo). La principal herramienta de investigación es un cuestionario. Su validez fue confirmada por las élites y su confiabilidad fue confirmada al completar 30 
cuestionarios a través del alfa de Cronbach en un nivel superior a 0,70. La población del estudio fue de 264375 ciudadanos que vivían en Neishabour. El tamaño de la muestra se determinó mediante la fórmula de Cochran igual a 384 personas. Los resultados mostraron que la agricultura urbana es significativa en el suministro de alimentos y la capacidad de exportación a un nivel inferior a 0,05. La agricultura de la ciudad puede ser eficaz para mejorar la exportación de productos orgánicos, frutas y verduras, la exportación de plantas ornamentales y medicinales, la marca de productos, así como en el suministro de verduras frescas, proporcionar alimentos saludables, mejorar la calidad de la nutrición y las proteínas. La agricultura urbana tiene un nivel significativo de menos de 0,05 en indicadores de desarrollo urbano como mejora del entorno urbano, mejora del empleo, mejora de los ingresos de los ciudadanos, creación de espacios urbanos atractivos, consumo de agua de lluvia, etc. Desde el punto de vista de las personas, es posible cultivar cultivos como melocotón, rosa de Damasco, cría de aves, etc., según los espacios disponibles. El estudio del papel de la agricultura urbana a través de ecuaciones estructurales muestra que el efecto total es 0,81 y en la agricultura urbana total puede explicar alrededor del $56 \%$ de la varianza del juego de roles y dos variables de satisfacción de las necesidades alimentarias y capacidad de exportación.

Palabras clave: agricultura urbana, alimentos, capacidad de exportación, ciudad de Neishabour.

\section{Introduction}

The growing trend of urban population, especially in developing countries, has posed countless opportunities and threats to managers and citizens.Today, some urban experts believe that cities, while being very efficient in the fields of economy and resource efficiency, are at the forefront of poverty alleviation and improving the quality of human life (Association of Cities Union, 2010). Many metropolitan residents are dissatisfied with the quality of life in these centers for reasons such as high housing prices, heavy traffic, environmental pollution, inadequate municipal services, unfair distribution of income, increased informal housing and, consequently, increased social anomalies. (Duvall, 1999). Many believe that urbanism is not the real cause of many urban problems, but the reason for these problems is the lack of proper urban management (Zahedi, 2007). One of the appropriate approaches to reduce various problems, including economic issues, is to emphasize the urban agriculture approach. The use of agriculture in urban spaces is aimed at stabilizing them according to the existing capacities in this field. Nearly all cities are built either along food production sources such as agricultural lands or at the mouths of rivers and coasts, or at the intersection of capital trade routes (Sznajder et al, 2009).

Cities formed in the vicinity of agricultural lands and gardens, in their current development, are devouring their original sources of formation and destroying their green infrastructure. In many countries, the weakness of macroeconomic structures that 
have led to the conversion of land into capital goods threatens most green lands in cities and suburbs. Therefore, it is necessary to turn to strategies and solutions that, in addition to warning the value of these lands for conservation, can make them a platform for the production of labor and capital (Walter et al, 2013). Urban agriculture is one of these strategies. Urban and suburban agriculture takes place in and around the borders of the world's cities and includes crops and livestock, fishing and arboriculture within cities (Smith et al, 1996). It also includes non-consumable products such as ecological services. In most cases, there are multiple farming and horticultural systems near cities. According to the FAO definition, the correct understanding of urban agriculture is that the diversity of agricultural and domestic activities leads to food security and income generation (Fao, 2008). In fact, urban agriculture refers to the process of producing any agricultural product within cities or their suburbs and can include growing food (vegetables, legumes, mushrooms and even meat and dairy), medicinal plants, shrubs and ornamental plants (Graefe et al., 2008). Urban agriculture is the cultivation, processing, and distribution of food in and around cities (Lee-Smith, 2010). In fact, it is a look at society and urban planning that links various urban planning and design clues to diverse agricultural and food systems (Clinton et al., 2018). Sustainable urban agricultural production can be significant compared to rural agriculture. Also, due to the scarcity of water and land resources in the city, urban agriculture uses only part of the resources used in rural agriculture (Simatele \& Binns, 2008). On the other hand, it can absorb some of the municipal solid and liquid wastes, which leads to cost reduction and waste management problems in the city (Martellozzo et al, 2014). People like to feel the taste and smell of fresh vegetables and fruits, watch their surroundings turn green and relax in a green environment. From box vase to local farms on abandoned land to tall trees on rooftops, urban agriculture is rapidly changing the world's cities. The idea is a simple one, to use all the space for agriculture and horticulture (Dossa et al, 2011). The results of studies show that the use of urban agriculture is not only effective in reducing environmental pollution, but also improves the quality of the environment and creates a healthy place to live in the city, but can also lead to income in these small urban spaces. The benefits of urban agriculture for the urban environment, especially in green roofs and vertical gardens, are to reduce the effects of heat island, improve air quality, increase biodiversity and sound insulation, and reduce greenhouse gas emissions (NCC). , 2008. Urban agriculture can also play a role in the social dimension of sustainability in cities. For example, urban gardens can create and improve environmental justice in marginalized and poorer areas (Ferris et al, 2001). Urban gardens can also be considered as a dynamic and participatory model of sustainability in action, through social interactions, environmental protection and organic food production (Holland, 2004). Economically, urban agriculture can play an effective role in achieving sustainability in cities by creating new jobs and professions, producing goods and services, and filling existing gaps in the marketing and sale of food products (Howe and Wheeler, 1999). A review of practical examples of urban agriculture also points to such effects. Urban agriculture has become common in cities around the world (Tuijl Erwin et al, 2018). In 1964, the Havana Green Belt was proposed to centralize agriculture within the city for a detailed plan of the city, and the townspeople were 
advised to grow fruits and vegetables wherever they could, which eventually helped the city grow (Viljoen et al, 2015). Detroit is one of the most active urban agricultural activists in the West with more than 800 urban gardens. Urban agriculture in this city not only reduced the unemployment rate of residents, but also had a positive effect on reducing crime rates (Hanna, 2000). 14\% of London's population of 7.5 million provide some of their food needs through urban agriculture (Angotti, 2015).

The city studied in this study is the city of Neishabour in Khorasan Razavi province in northeastern Iran. According to the latest statistics of 2016, the population of Neishabour is equal to 264,375 people and 83,143 households (Statistics Center of Iran, 2016). A study of the area under cultivation, production and yield of crops in the region in 2014 shows that more than 58,537 hectares of land are under wheat cultivation. The amount of production is 93208 tons. Wheat production Performance is equal to $2450 \mathrm{~kg}$ per hectare of watered and $326 \mathrm{~kg}$ per hectare of rain fed. Crops such as chickpeas, alfalfa, wheat, barley are grown in both rain fed and watered. Other crops such as sugar beet, cotton, melon, cucumber, potato, onion, strawberry, eggplant, bean, corn, etc. are grown only watered in the region. A variety of horticultural products such as apples, pears, plums, cherries, peaches, almonds, rhubarb and grapes are grown in this area, which indicates the appropriate capacity of horticultural products in the field of emphasis and planning for urban agriculture. For example, we can mention $42585 \mathrm{~kg}$ of apple production, $3150 \mathrm{~kg}$ of pears, $11837 \mathrm{~kg}$ of grape production in the region (Agricultural Jihad Organization, 2018).

Neishabour is a multi-role city in terms of economy and a middle city in terms of scale, which includes the service sector, the main part of the city's economy. Considering the economic capacities of this city, its multi-role, young manpower, suitable natural features and development of various economic sectors in the horizon of 1405 , it seems that the policy on the development of urban agriculture can pave the way for the development of this Provide the department and propel a large part of the manpower to urban agriculture and the use of unused or cultivated spaces. Therefore, considering the natural and human characteristics on the one hand and also the existence of some restrictions on the economic development of the city, it seems that planning in the field of urban agriculture can be considered a suitable approach in Neishabour. Since it is an important dimension of urban agriculture economically and can help the development of this sector in cities, the main purpose of this article is to examine the role of urban agriculture in food supply and export ability. Another point is that cities in the agricultural sector usually play a lesser export role in terms of production and export of products, and focusing on this approach can be effective in improving these indicators. The results of this study can be effective in implementing this approach for medium-scale cities and help to expand them.

\section{Case study of the city}

The city of Neishabour is known as the second most populous city in Khorasan Razavi after the city of Mashhad with a population of 264,375 people and 83,143 
households in 2016 (Statistics Center of Iran, 2016). Neishabour city is located in the center of Khorasan Razavi at a latitude of 36 degrees and 15 minutes and a longitude of 58 degrees and 50 minutes from the Greenwich meridian is the center of Neishabour city. The altitude of the city is 1212 meters above sea level. It has a suitable climate. The average annual temperature in this city is 14.8 degrees Celsius. The average total annual rainfall of Neishabour is 1/235 mm (Meteorological Organization of Iran, 2019). The study of the population of Neishabour from 1926 to 2016 shows that the population trend has been increasing. So that the population of the city in 1335 was equal to 25820 people and 5868 families. In 1345, the population of the city was equal to 34482 people and 7496 families. This statistic has increased to 205972 people and 56652 households in 1385 and to 239185 people and 711263 households in 1390. The population of the city in 2016 reached 264,375 people. In general, the population trend of the city has been increasing (Statistics Center of Iran, 1335-1395). The forecast of employment developments also shows that the number of employees can increase from 64587 people in 1385 to 98171 people in 1405 people. Also, the agricultural sector will reach 6075 jobs in 1405. The annual growth of the agricultural sector in the period 1385 to 1405 is equal to 1.2 percent, the industrial sector equal to 2.7 percent and the service sector equal to 1.8 percent (Agricultural Jihad Organization, 2018).

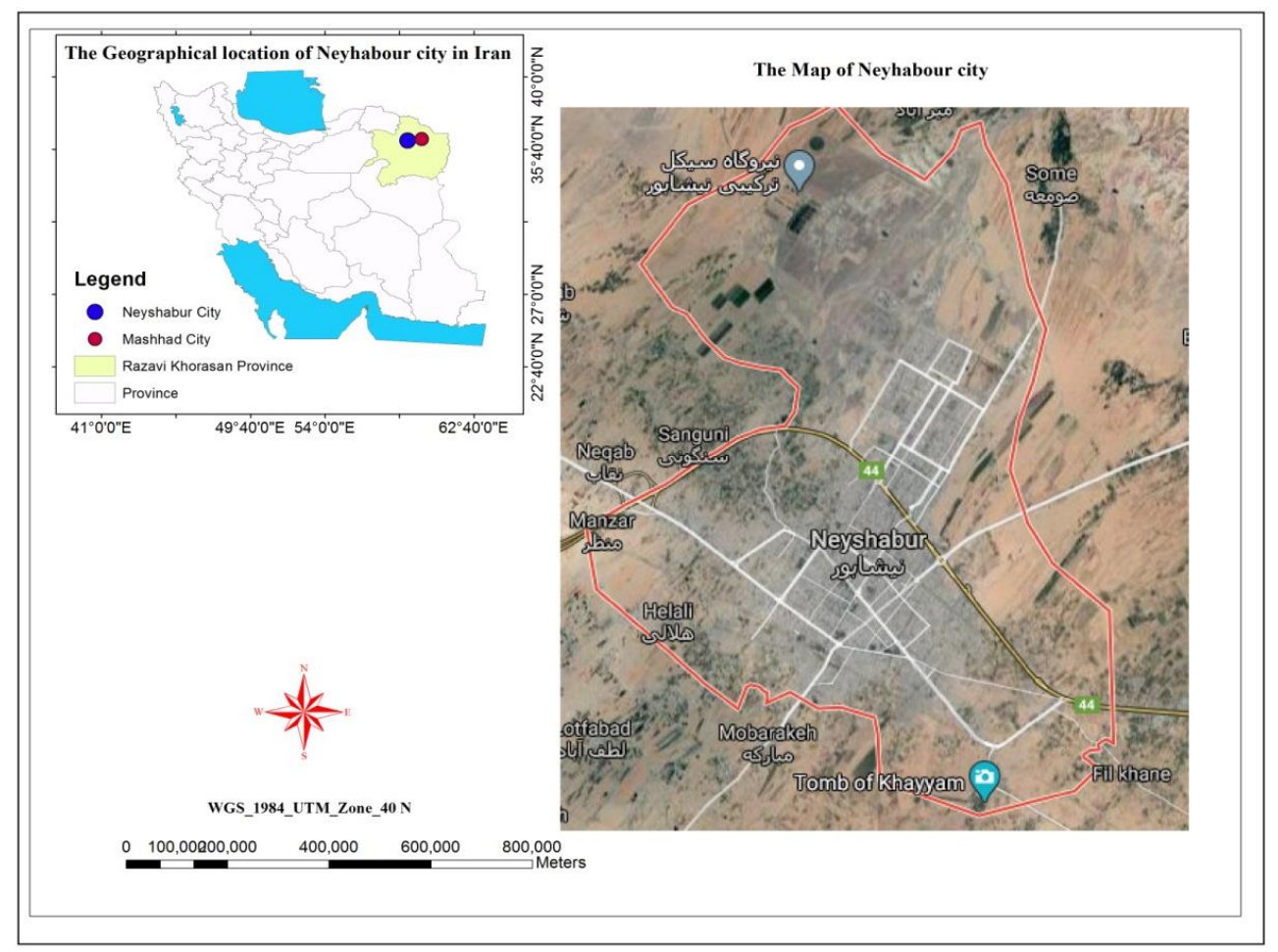

Figure 1

Location of Neishabour city in Iran and around the city

\section{Materials and methods}

The research is applied in terms of purpose and in terms of nature and descriptiveanalytical method. Field studies (survey) method was used to collect data. Field studies 
are based on a questionnaire that was completed by the citizens of Neishabour. The statistical population of the study was 264,375 people. Due to the fact that it was not possible to study all people using the Cochran's formula, the sample size was calculated to be 384 people. In this formula, $\mathrm{n}=$ sample size; $\mathrm{z}=$ value of standard normal distribution statistic 1.96; $\mathrm{d}=$ optimal probability accuracy $(1 / 0) ; \mathrm{N}=$ number of members of the whole community (264375); $\mathrm{p}=$ probability of adjective $(0.5)$ and $\mathrm{q}=$ probability of no adjective (5/0).

$n=\frac{N z^{\gamma} p q}{N d^{\gamma}+z^{\gamma} p q}$

128 people were interviewed for three urban areas in equal numbers. In this study, the opinions of experts, university professors and doctoral students were used to validate the questionnaire. To determine the reliability of the questionnaire, 30 questionnaires were randomly completed in the neighborhoods and Cronbach's alpha coefficient was calculated for the variables. For all variables, the obtained value was more than 0.70 . Therefore, reliability for data was obtained based on the questionnaire tool (Table 1.).

Table 1

Cronbach's alpha coefficient for research variables

\begin{tabular}{|l|l|l|l|}
\hline Variable & Indicator & $\begin{array}{l}\text { Number of } \\
\text { indicators }\end{array}$ & $\begin{array}{l}\text { Cronbach's alpha } \\
\text { coefficients }\end{array}$ \\
\hline Food supply & Listed in Table 4 & 9 & $81 \%$ \\
\hline Ability to export & Listed in Table 5 & 8 & $70 \%$ \\
\hline $\begin{array}{l}\text { The role of } \\
\text { agriculture in the } \\
\text { sustainable } \\
\text { development of the } \\
\text { city }\end{array}$ & Listed in Table 6 & 12 & $73 \%$ \\
\hline
\end{tabular}

The questioner operation was carried out randomly at the citizen level. Data were analyzed using SPSS software and inferred. One-sample t-test, mean and structural equation modeling were used to analyze the data and generalize the sample size results to the population.

\section{Results and discussion}


In terms of the Indicator of citizens' interest in agriculture in the city, the results show that more than $28.9 \%$ of people have overestimated their interest in agriculture. $18.2 \%$ rated it as very high and $33.3 \%$ as moderate. Therefore, more than $80 \%$ of people have rated their interest in agriculture as moderate to high, and as a result, there are mental and interest areas.

Table 2

Statistical distribution of respondents in terms of interest in agriculture

\begin{tabular}{ccc}
\hline $\begin{array}{c}\text { The level of interest in } \\
\text { agriculture }\end{array}$ & Frequency & percentage \\
\hline very little & 37 & $9 / 6$ \\
Low & 38 & $9 / 9$ \\
Medium & 128 & $33 / 3$ \\
Much & 111 & $28 / 9$ \\
very much & 70 & $18 / 2$ \\
\hline Total & 384 & 100 \\
\hline
\end{tabular}

In terms of the possibility of cultivating crops in the spaces of Neishabour, the results of the sample size show that more than $32.8 \%$ of people have chosen a very high option compared to this index and $33.1 \%$ have chosen a high option. Therefore, more than $65.9 \%$ of people have considered the possibility of cultivating crops in different areas of Neishabour possible and have shown interest in this approach.

Table 3

Statistical distribution of respondents in terms of the possibility of cultivating crops in Neishabour

\begin{tabular}{ccc}
\hline $\begin{array}{c}\text { The possibility of } \\
\text { cultivating crops in the }\end{array}$ & Frequency & percentage \\
\hline verv little & 38 & $9 / 9$ \\
Low & 38 & $9 / 9$ \\
Medium & 55 & $14 / 3$ \\
Much & 127 & $33 / 1$ \\
very much & 126 & $32 / 8$ \\
\hline Total & 284 & 100 \\
\hline
\end{tabular}

The role of urban agriculture in meeting food needs from the perspective of citizens

Whether agriculture can be effective in meeting food needs should be assessed. The results of one-sample t-test show that all indicators of variable nutritional needs are at a significant level of less than 0.05. Based on the difference between the mean and the 
mean, which is more than the criterion, ie the number 3, it can be concluded that each of the indicators of meeting food needs is in a good position. The upper and lower Indicators of the indicators also confirm this; 9 food supply indicators can be improved and improved under the influence of agriculture. Also, the study of the total scale of indicators through one-sample t-test shows that it is at a significance level of less than 0.05 . The mean difference is equal to 0.76 and the mean is equal to 3.76 . This means that agriculture can be effective in providing food from the citizens' point of view. Therefore, urban agriculture can play a role in improving the supply of fresh vegetables, supply of organic products, supply of fresh fruit, supply of healthy food, supply of agricultural products (countryside), improving the quality of nutrition of citizens and supply of protein materials. Improve and develop indicators. Accordingly, the approach of urban agriculture from the perspective of citizens in meeting the diverse food needs can be effective and inspire in various ways. This role-playing is not only effective in the economy of urban households, but also helps to improve social indicators.

Table 4

Investigating the role of urban agriculture in food needs with a single t-test of citizens' perspectives

\begin{tabular}{|c|c|c|c|c|c|c|}
\hline \multirow[t]{3}{*}{ Indicator } & \multirow{3}{*}{$\mathbf{T}$} & \multirow{3}{*}{$\begin{array}{c}\text { Degrees } \\
\text { of } \\
\text { freedom }\end{array}$} & \multicolumn{2}{|c|}{ Test basis $=3$} & \multirow{2}{*}{\multicolumn{2}{|c|}{$\begin{array}{c}95 \% \\
\text { confidence } \\
\text { interval }\end{array}$}} \\
\hline & & & $\begin{array}{c}\text { The } \\
\text { significance } \\
\text { level }\end{array}$ & $\begin{array}{c}\text { Difference } \\
\text { from the } \\
\text { mean }\end{array}$ & & \\
\hline & & & & & $\begin{array}{l}\text { Low } \\
\text { limit }\end{array}$ & $\begin{array}{l}\text { Upper } \\
\text { limit }\end{array}$ \\
\hline Supply of fresh & $10 / 89$ & 383 & $0 / 000$ & $0 / 64$ & $0 / 52$ & $0 / 75$ \\
\hline $\begin{array}{l}\text { Supply of } \\
\text { organic products }\end{array}$ & $12 / 35$ & 383 & $0 / 000$ & $0 / 81$ & $0 / 68$ & $0 / 94$ \\
\hline $\begin{array}{l}\text { Supply of fresh } \\
\text { fruit }\end{array}$ & $8 / 37$ & 383 & $0 / 000$ & $0 / 56$ & $0 / 43$ & $0 / 69$ \\
\hline $\begin{array}{l}\text { Provide healthy } \\
\text { food }\end{array}$ & $15 / 28$ & 383 & $0 / 000$ & 0/91 & $0 / 80$ & $1 / 03$ \\
\hline $\begin{array}{l}\text { Ensuring food } \\
\text { security }\end{array}$ & $12 / 92$ & 383 & $0 / 000$ & $0 / 85$ & $0 / 72$ & 0/98 \\
\hline $\begin{array}{lr}\text { Improving } & \text { the } \\
\text { quality } & \text { of } \\
\text { nutrition } & \text { of } \\
\text { citizens } & \end{array}$ & $9 / 57$ & 383 & $0 / 000$ & $0 / 62$ & $0 / 49$ & $0 / 75$ \\
\hline
\end{tabular}




\begin{tabular}{|c|c|c|c|c|c|c|}
\hline $\begin{array}{l}\text { Improving the } \\
\text { food basket of } \\
\text { citizens }\end{array}$ & $10 / 34$ & 383 & $0 / 000$ & $0 / 71$ & $0 / 57$ & $0 / 84$ \\
\hline $\begin{array}{l}\text { Supply } \\
\text { agricultural } \\
\text { products } \\
\text { (suburbs) }\end{array}$ & $12 / 80$ & 383 & $0 / 000$ & $0 / 83$ & $0 / 71$ & $0 / 96$ \\
\hline $\begin{array}{l}\text { Supply of } \\
\text { protein materials }\end{array}$ & $13 / 84$ & 383 & $0 / 000$ & $0 / 91$ & $0 / 78$ & $1 / 03$ \\
\hline Sum of scales & $16 / 83$ & 383 & $0 / 00$ & $0 / 76$ & $0 / 67$ & $0 / 85$ \\
\hline
\end{tabular}

\section{The role of urban agriculture in the ability to export from the perspective of citizens}

In this section, the ability to export to other regions in the form of 8 indicators was examined through a one-sample t-test. The test results show that all indicators are at a significance level of less than 0.05. Based on the mean difference, which is positive for all indicators. It can be concluded that the indicators of export ability to other regions are in good condition; Because the difference of the positive mean indicates that the mean of the indicators is higher than the value of the criterion(3). Based on this, it should be concluded that the measured indicators in terms of export ability to other regions are in a good position. In other words, urban agriculture can be effective in terms of exports from the perspective of citizens.

Also, the total scale of the indicators is at a significance level of less than 0.05 . The average difference is 0.77 . Based on this, it should be concluded that the agriculture of Neishabour city, considering its different capacities, can pave the way for favorable developments, including in the export sector. These roles and effects include improving the export of organic products, improving the export of fruits and vegetables, exporting the food industry, increasing the export of ornamental and medicinal plants, price and value of exported products, branding of exported products, improving and packaging of exported products and exporting agriculture products pointed out. In fact, the city of Neishabour has a suitable capacity in the field of cultivation and harvesting of various products, and considering that this capacity exists, a better plan should be developed for its export. In fact, urban agriculture can not only help the livelihood of people living in the city, but with proper planning, it has the ability to export to other areas.

\section{Table 5}


Investigating the role of urban agriculture in the ability to export with a single $t$ test of citizens' perspectives

\begin{tabular}{|c|c|c|c|c|c|c|}
\hline \multirow[t]{3}{*}{ Indicator } & \multicolumn{6}{|c|}{ Test basis $=3$} \\
\hline & \multirow[t]{2}{*}{$\mathbf{T}$} & \multirow{2}{*}{$\begin{array}{l}\text { Degrees } \\
\text { of } \\
\text { freedom }\end{array}$} & \multirow{2}{*}{$\begin{array}{c}\text { The } \\
\text { significance } \\
\text { level }\end{array}$} & \multirow{2}{*}{$\begin{array}{l}\text { Difference } \\
\text { from the } \\
\text { mean }\end{array}$} & \multicolumn{2}{|c|}{$\begin{array}{c}95 \% \text { confidence } \\
\text { interval }\end{array}$} \\
\hline & & & & & $\begin{array}{l}\text { Low } \\
\text { limit }\end{array}$ & $\begin{array}{l}\text { Upper } \\
\text { limit }\end{array}$ \\
\hline $\begin{array}{l}\text { Improving the export of } \\
\text { organic products }\end{array}$ & $13 / 41$ & 383 & $0 / 000$ & $0 / 92$ & $0 / 78$ & $1 / 05$ \\
\hline $\begin{array}{l}\text { Improve fruit and } \\
\text { vegetable exports }\end{array}$ & $9 / 38$ & 383 & $0 / 000$ & $0 / 62$ & $0 / 49$ & $0 / 75$ \\
\hline Food industry exports & $13 / 24$ & 383 & $0 / 000$ & $0 / 82$ & $0 / 70$ & $0 / 94$ \\
\hline $\begin{array}{l}\text { Increasing the export of } \\
\text { ornamental and } \\
\text { medicinal plants }\end{array}$ & $13 / 78$ & 383 & $0 / 000$ & $0 / 91$ & $0 / 78$ & $1 / 04$ \\
\hline $\begin{array}{l}\text { Price and value of } \\
\text { export products }\end{array}$ & $9 / 21$ & 383 & $0 / 000$ & $0 / 57$ & $0 / 45$ & $0 / 69$ \\
\hline $\begin{array}{l}\text { Branding of export } \\
\text { products }\end{array}$ & $14 / 20$ & 383 & $0 / 000$ & $0 / 90$ & $0 / 78$ & $1 / 03$ \\
\hline $\begin{array}{l}\text { Improvement and } \\
\text { packaging of export } \\
\text { products }\end{array}$ & $10 / 89$ & 383 & $0 / 000$ & $0 / 64$ & $0 / 52$ & $0 / 75$ \\
\hline Export of crops & $12 / 35$ & 383 & $0 / 000$ & $0 / 81$ & $0 / 68$ & $0 / 94$ \\
\hline Sum of scales & $18 / 52$ & 383 & $0 / 00$ & $0 / 77$ & $0 / 69$ & $0 / 86$ \\
\hline
\end{tabular}

Assessing the role of agriculture in the sustainable development of the city from the perspective of citizens

In order to study the role of agriculture in the sustainable development of Neishabour, citizens have been asked to express their views in this opinion. According to studies, agriculture can have an impact on 12 main indicators and be effective in the development of the city. The results of one-sample t-test show that all indicators are at a significance level of less than 0.05. Based on the average difference, it can be concluded that 12 indicators have a positive average difference, which means that agriculture is effective in these 12 indicators of urban development. These indicators include 
improving the city's environment, improving the city's air quality, improving the city's employment, improving citizens' incomes, increasing the city's food industry, creating attractive urban spaces, consuming rainwater (through gutters), and becoming economical the unused spaces of the city, the reduction of waste and waste in the city and the improvement of tourism due to the attractive and green landscape of the city.

Also, the study of the total scale of indicators through one-sample t-test shows that it is at a significance level of less than 0.05 . The average difference is 0.77 . This means that agriculture plays an important role in urban development indicators. In general, agriculture can have many positive effects from the economic, social and environmental points of view, but what is important is the correct knowledge of the issues and proper planning for the sustainable development of the city. In fact, agriculture in the city of Neishabour should be planned in a way that has positive results and not aggravate various social, economic and environmental issues of the city.

Table 6

Evaluating the role of agriculture in the Stable development of Neishabour city with a single t-test of citizens' perspectives

\begin{tabular}{|c|c|c|c|c|c|c|}
\hline \multirow[t]{3}{*}{ Indicator } & \multicolumn{6}{|c|}{ Test basis $=3$} \\
\hline & \multirow[t]{2}{*}{$\mathbf{T}$} & \multirow{2}{*}{$\begin{array}{l}\text { Degrees } \\
\text { of } \\
\text { freedom }\end{array}$} & \multirow{2}{*}{$\begin{array}{c}\text { The } \\
\text { significance } \\
\text { level }\end{array}$} & \multirow{2}{*}{$\begin{array}{l}\text { Difference } \\
\text { from the } \\
\text { mean }\end{array}$} & \multicolumn{2}{|c|}{$\begin{array}{l}95 \% \text { confidence } \\
\text { interval }\end{array}$} \\
\hline & & & & & $\begin{array}{l}\text { Low } \\
\text { limit }\end{array}$ & $\begin{array}{l}\text { Upper } \\
\text { limit }\end{array}$ \\
\hline $\begin{array}{l}\text { Improving the city } \\
\text { environment }\end{array}$ & $10 / 23$ & 383 & $0 / 000$ & $0 / 70$ & $0 / 56$ & $0 / 83$ \\
\hline Improving city air quality & $12 / 70$ & 383 & $0 / 000$ & $0 / 83$ & $0 / 70$ & $0 / 95$ \\
\hline Improve city employment & $14 / 23$ & 383 & $0 / 000$ & $0 / 92$ & $0 / 80$ & $1 / 05$ \\
\hline Improving citizens' incomes & $13 / 35$ & 383 & $0 / 000$ & $0 / 92$ & $0 / 78$ & $1 / 05$ \\
\hline $\begin{array}{l}\text { Increasing food industry in the } \\
\text { city }\end{array}$ & $10 / 93$ & 383 & $0 / 000$ & $0 / 69$ & $0 / 57$ & $0 / 81$ \\
\hline $\begin{array}{l}\text { Increase the physical activity } \\
\text { of citizens }\end{array}$ & $14 / 07$ & 383 & $0 / 000$ & $0 / 85$ & $0 / 73$ & 0/97 \\
\hline $\begin{array}{l}\text { Improving the food health of } \\
\text { citizens }\end{array}$ & $15 / 01$ & 383 & $0 / 000$ & $0 / 96$ & $0 / 84$ & $1 / 09$ \\
\hline Create attractive urban spaces & $9 / 58$ & 383 & $0 / 000$ & $0 / 59$ & $0 / 47$ & $0 / 71$ \\
\hline
\end{tabular}




\begin{tabular}{|c|c|c|c|c|c|c|}
\hline $\begin{array}{l}\text { Reduce the city's waste and } \\
\text { scrap }\end{array}$ & $14 / 48$ & 383 & $0 / 000$ & $0 / 91$ & $0 / 79$ & $1 / 04$ \\
\hline $\begin{array}{l}\text { Economization of spaces } \\
\text { without urban use }\end{array}$ & $11 / 27$ & 383 & $0 / 000$ & $0 / 65$ & $0 / 54$ & $0 / 77$ \\
\hline $\begin{array}{l}\text { Rainwater consumption } \\
\text { (through gutters) }\end{array}$ & $13 / 48$ & 383 & $0 / 000$ & $0 / 86$ & $0 / 74$ & 0/99 \\
\hline $\begin{array}{l}\text { Improving tourism due to the } \\
\text { attractive and green landscape }\end{array}$ & $5 / 56$ & 383 & $0 / 000$ & $0 / 38$ & $0 / 24$ & $0 / 51$ \\
\hline Sum of scales & $20 / 09$ & 383 & $0 / 00$ & $0 / 77$ & $0 / 70$ & $0 / 85$ \\
\hline
\end{tabular}

Recognizing the cultivation of the best agricultural products in the city of Neishabour from the perspective of citizens

Study and recognition of cultivation of the best agricultural products in Neishabour from the citizens' point of view according to their experiences, through one-sample $t$ test shows that all products are at a significant level of less than 0.05. The average difference is 0.37 . Also, the upper and lower limits, which are positive and do not contain the number zero, also confirm this. From the people's point of view, the 20 products mentioned in Table (7) can be cultivated in the city of Neishabour, and only the necessary spaces for each case should be identified. From the people's point of view, according to the available spaces, it is possible to cultivate crops such as peaches, damask rose, poultry, sheep in the suburbs, vegetables, almonds, apples, rhubarb, etc.

\section{Table 7}

Investigating and recognizing the cultivation of the best agricultural products in the city of Neishabour with a single t-test of citizens' perspectives

\begin{tabular}{|c|c|c|c|c|c|c|}
\hline \multirow[t]{3}{*}{ Indicator } & \multicolumn{6}{|c|}{ Test basis $=3$} \\
\hline & \multirow[t]{2}{*}{$\mathbf{T}$} & \multirow{2}{*}{$\begin{array}{l}\text { Degrees } \\
\text { of } \\
\text { freedom }\end{array}$} & \multirow{2}{*}{$\begin{array}{l}\text { The } \\
\text { significance } \\
\text { level }\end{array}$} & \multirow{2}{*}{$\begin{array}{l}\text { Difference } \\
\text { from the } \\
\text { mean }\end{array}$} & \multicolumn{2}{|c|}{$\begin{array}{l}95 \% \text { confidence } \\
\text { interval }\end{array}$} \\
\hline & & & & & $\begin{array}{l}\text { Low } \\
\text { limit }\end{array}$ & $\begin{array}{l}\text { Upper } \\
\text { limit }\end{array}$ \\
\hline Damask rose & $4 / 77$ & 383 & $0 / 00$ & $0 / 27$ & $0 / 16$ & $0 / 39$ \\
\hline Pistachio & $5 / 22$ & 383 & $0 / 00$ & $0 / 31$ & $0 / 19$ & $0 / 43$ \\
\hline $\begin{array}{l}\text { Flowers and } \\
\text { ornamental }\end{array}$ & $6 / 12$ & 383 & $0 / 00$ & $0 / 28$ & $0 / 19$ & $0 / 37$ \\
\hline Jujube & $2 / 03$ & 383 & $0 / 04$ & $0 / 10$ & $0 / 00$ & $0 / 21$ \\
\hline Almond & $7 / 70$ & 383 & $0 / 00$ & $0 / 41$ & $0 / 31$ & $0 / 52$ \\
\hline Apple & $7 / 48$ & 383 & $0 / 00$ & $0 / 47$ & $0 / 34$ & $0 / 59$ \\
\hline Lentils & $17 / 12$ & 383 & $0 / 00$ & $0 / 96$ & $0 / 85$ & $1 / 07$ \\
\hline
\end{tabular}




\begin{tabular}{lllllll}
\hline Wheat & $9 / 46$ & 383 & $0 / 00$ & $0 / 59$ & $0 / 47$ & $0 / 71$ \\
grain & $3 / 95$ & 383 & $0 / 00$ & $0 / 26$ & $0 / 13$ & $0 / 39$ \\
Corn & $4 / 57$ & 383 & $0 / 00$ & $0 / 27$ & $0 / 16$ & $0 / 39$ \\
cotton & $2 / 25$ & 383 & $0 / 02$ & $0 / 13$ & $0 / 02$ & $0 / 25$ \\
Plum & $7 / 57$ & 383 & $0 / 00$ & $0 / 45$ & $0 / 33$ & $0 / 56$ \\
the vegetables & $3 / 50$ & 383 & $0 / 00$ & $0 / 20$ & $0 / 09$ & $0 / 31$ \\
rhubarb & $4 / 04$ & 383 & $0 / 00$ & $0 / 26$ & $0 / 13$ & $0 / 38$ \\
Beans & $5 / 07$ & 383 & $0 / 00$ & $0 / 30$ & $0 / 19$ & $0 / 42$ \\
Peach & $4 / 32$ & 383 & $0 / 00$ & $0 / 28$ & $0 / 15$ & $0 / 40$ \\
Pea & $7 / 42$ & 383 & $0 / 00$ & $0 / 45$ & $0 / 33$ & $0 / 57$ \\
Sheep & $13 / 02$ & 383 & $0 / 00$ & $0 / 73$ & $0 / 62$ & $0 / 84$ \\
Cattle and calves & $5 / 47$ & 383 & $0 / 00$ & $0 / 33$ & $0 / 21$ & $0 / 45$ \\
Poultry breeding & $6 / 44$ & 383 & $0 / 00$ & $0 / 39$ & $0 / 27$ & $0 / 51$ \\
(chicken Other, & & & & & & \\
Other & $5 / 48$ & 383 & $0 / 00$ & $0 / 32$ & $0 / 21$ & $0 / 44$ \\
\hline Sum of scales & $16 / 60$ & 383 & $0 / 00$ & $0 / 37$ & $0 / 33$ & $0 / 41$ \\
\hline
\end{tabular}

\section{Assessing the role of agriculture in providing food needs and export ability with structural equations}

The role of agriculture in providing food needs and export ability from the perspective of citizens has also been assessed using structural equations. Factor loads related to the indicators of the model are higher than 0.3 and indicate the acceptable status of the indicators in the model. In fact, the study of the fit of the model of the role of agriculture in providing food needs and export ability from the perspective of citizens with the values of the model has the necessary validity and accuracy and has been able to explain the role of agriculture in providing food needs and export ability from the perspective of citizens (Table 8). All indicators correspond to the recommended and standard values. The factor load of 17 indicators of food supply and export ability is equal to 0.81 , and this indicates the appropriate effect of the agricultural variable on food supply and export ability from the perspective of citizens. 


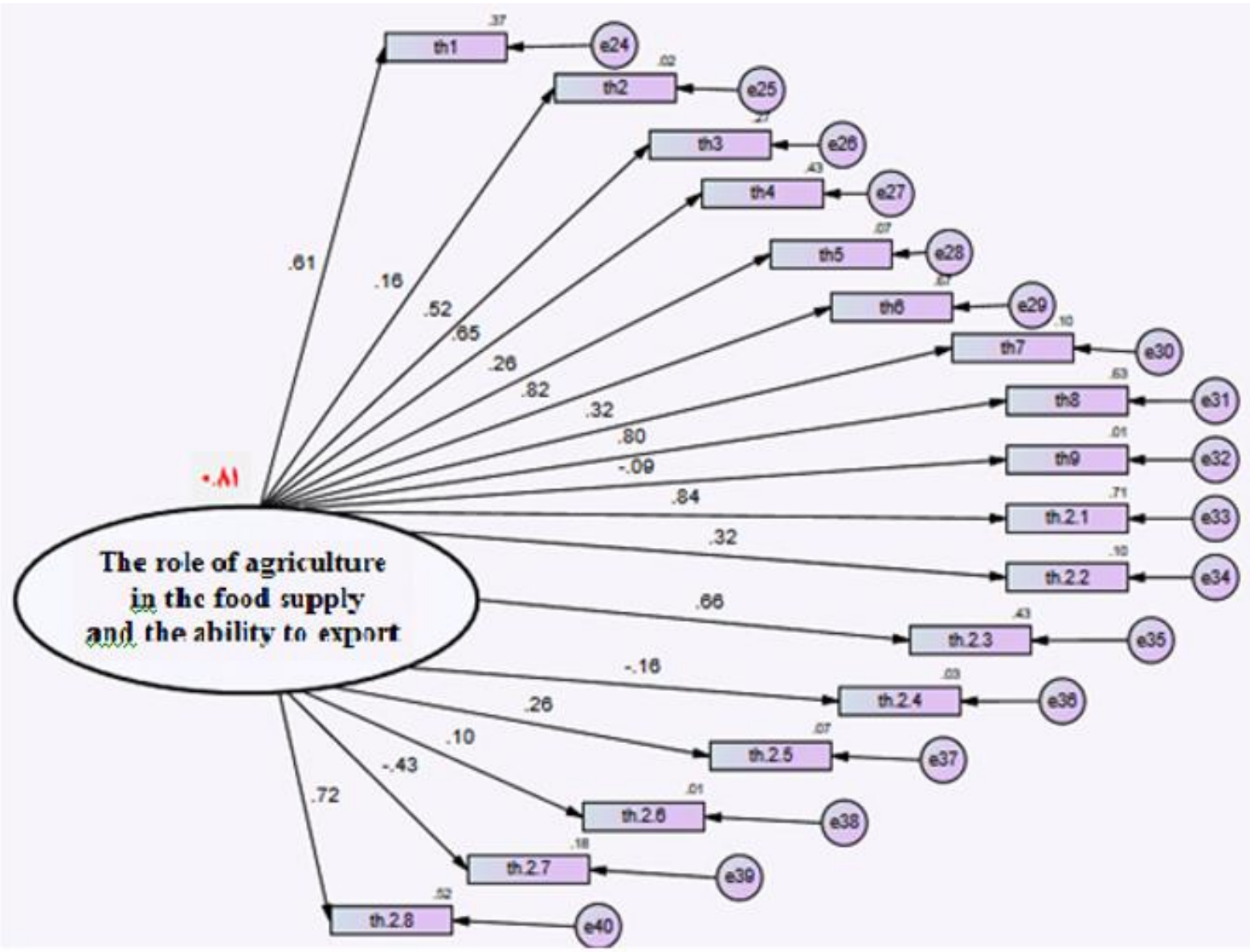

Figure 2

The final model of the structural equation of the role of agriculture in providing food needs and export ability from the perspective of citizens

Table 8

Indicators for evaluating the whole role of agriculture in providing food needs and export ability from the perspective of citizens

\begin{tabular}{|l|l|l|l|l|l|l|l|l|l|l|}
\hline Indicator & CMIN & DF & CMIN/DF & CFI & RMSEA & HOELTER & RMR & GFI & NFI & PRATIO \\
\hline $\begin{array}{l}\text { The final } \\
\text { model }\end{array}$ & $18 / 123$ & 6 & $3 / 265$ & $0 / 951$ & $0 / 067$ & 167 & $0 / 043$ & $0 / 976$ & $0 / 992$ & $0 / 240$ \\
\hline $\begin{array}{l}\text { Suggested } \\
\text { values }\end{array}$ & - & - & - & $0 / 9>$ & $0 / 08<$ & $75>$ & $0 \approx$ & $0 / 9>$ & $0 / 9>$ & $0-1$ \\
\hline
\end{tabular}

After examining the overall processing of the agricultural role model in providing food needs and export ability from the perspective of citizens, the effect of the independent variable on the dependent variable of the research was investigated. As can be seen (Table 9), the role of agriculture in providing food needs and the ability to export from the perspective of citizens among respondents is significant at the level of $99 \%$ confidence. The higher of the estimated critical ratio (8.496) than the value of 2.58 (critical ratio higher than 2.58 indicates the significance of the effect), also indicates the 
significance of the effect of the independent variable of research (agriculture) on the dependent variable (meeting the needs Food and export ability). In general, it can be said that urban agriculture can be effective in two variables of providing food needs and export ability from the perspective of citizens. Examining the role of urban agriculture in improving economic indicators shows that the total effect is 0.81 and in total urban agriculture can explain about $56 \%$ of the role variance and the two variables of providing food needs and export ability.

Table 9

Estimation of standard, non-standard and the role of agriculture in providing food needs and export ability from the perspective of citizens

\begin{tabular}{|c|c|c|c|c|c|c|c|}
\hline \multirow{2}{*}{$\begin{array}{l}\text { Independe } \\
\text { nt variable }\end{array}$} & \multirow{2}{*}{$\begin{array}{l}\text { Depende } \\
\text { nt } \\
\text { variable }\end{array}$} & \multicolumn{2}{|c|}{ Estimation } & \multirow{2}{*}{$\begin{array}{l}\text { Critic } \\
\text { al } \\
\text { ratio }\end{array}$} & \multirow[b]{2}{*}{\begin{tabular}{|l} 
Tota \\
l \\
effec \\
$t$
\end{tabular}} & \multirow[b]{2}{*}{$\begin{array}{l}\text { The } \\
\text { coefficient } \\
\text { of } \\
\text { determinati } \\
\text { on } \mathbf{R}^{2}\end{array}$} & \multirow{2}{*}{$\begin{array}{l}\text { Significan } \\
\text { ce level }\end{array}$} \\
\hline & & $\begin{array}{l}\text { standar } \\
\text { d }\end{array}$ & $\begin{array}{l}\text { non- } \\
\text { standar } \\
\text { d }\end{array}$ & & & & \\
\hline $\begin{array}{l}\text { Urban } \\
\text { agriculture }\end{array}$ & $\begin{array}{l}\text { providing } \\
\text { food } \\
\text { needs and } \\
\text { export } \\
\text { ability }\end{array}$ & $0 / 546$ & $0 / 465$ & $8 / 496$ & $0 / 81$ & $0 / 56$ & $0 / 000$ \\
\hline
\end{tabular}

\section{Conclusion}

The results of this study show that there are grounds for creating and developing this approach in the study city as a medium-scale city. The level of interest of citizens in agriculture in urban spaces and their views on the possibility of growing crops in urban spaces is indicative of this. These results can indicate the willingness and participation of the people in the implementation of this approach and the initial context can be imagined with these conditions. This result itself is very useful; Because in order to implement any plan and program, the existence of an initial mentality among its citizens can solve many problems and obstacles and help to better implement and integrated participation of citizens.

The result shows that the indicators of export ability to other regions are in good condition and agriculture in Neishabour can be the basis for different developments according to its different capacities. These roles and effects include improving the export of organic products, improving the export of fruits and vegetables, exporting the food industry, increasing the export of ornamental and medicinal plants, price and value of exported products, branding of exported products, improving and packaging of exported products and exporting products agriculture pointed out. The results showed that agriculture can improve various indicators of food needs, including improving the supply of fresh vegetables, supply of organic products, supply of fresh fruit, supply of healthy food, supply of crops (suburbs), improving the quality of nutrition of citizens 
and supply of materials Protein is involved. Therefore, urban agriculture can be successful in providing the food needs of the people from the citizens' point of view and will also provide the ability to export to other regions. Neishabour can cultivate a variety of crops such as damask rosey, rhubarb, pistachios, corn and other items. However, there may be differences in the amount of each as well as limitations. In fact, evaluation indicates the possibility of cultivating them.

Agriculture can be effective in developing urban development indicators, including their sustainability. These indicators include improving the city's environment, improving the city's air quality, improving the city's employment, improving citizens' incomes, increasing the city's food industry, creating attractive urban spaces, consuming rainwater (through gutters), and becoming economical. Unused urban spaces, reduction of waste and waste of the city and improvement of tourism due to the attractive and green landscape of the city. These indicators can be achieved by developing and implementing an urban agriculture approach, especially in small and medium-sized cities; because by creating cultural contexts and acquainting people with agriculture and various products, not only the urban agriculture approach is applicable, but also by implementing this approach, we can also help develop urban development indicators. Urban agriculture, as mentioned, can have appropriate effects on various social, economic and environmental dimensions, and these impacts themselves are part of sustainable urban development.

In general, urban agriculture can play an effective role in food supply and export. This role-playing is about 56\%. In fact, agriculture can be 56 percent effective in improving these two variables in the city. Therefore, urban agriculture as a viable approach can create appropriate effects on the urban economy and help improve the existing conditions. What is important in this regard is to formulate a specific framework from promoting this approach among citizens to the spiritual and financial support that should be provided to citizens in this regard. According to these results, in order to realize this approach, there are solutions that include the promotion and training of cultivation among citizens in small spaces, the establishment of workshops and cooperative companies supporting and exporting, branding products, financial support for participants In the urban agriculture plan, he mentioned the holding of an annual festival for citizens and advice and guidance for the use of construction spaces and the cultivation of crops.

\section{References}

Binns, J., \& Nel, E. (2019). Reconceptualizing Urban Agriculture in Africa: Issues of Scale, Class and Institutional Support in Zambian Copperbelt Towns. Urban Food Democracy and Governance in North and South, 28(3), 213-229.

Clinton, N., Stuhlmacher, M., \&Miles, A. (2018). A global geospatial ecosystem services estimate of urban agricultura. Earths Future 6, 40-60. 
Dossa, H. L., Buerkert, A., \& Schlech, E. (2011). Cross-Location Analysis of the Impact of Household Socioeconomic Status on Participation in Urban and Peri-Urban Agriculture in West Africa. Human Ecology, 39(1), 569-581.

Duvall, J. (1999). Contemporary Choices for Citizens, in Roger L. Kemp, ed. Forms of LocalGovernment: A Handbook on City, County and Regional Options, Jefferson, NC: McFarland \& Co.

Fao. (2008). A report about Urban Agriculture, New York. UN press.

Ferris, J., Norman, C, \& Sempik, J. (2001). People, land and sustainability: community gardens and the social dimension of sustainable development. Social Policy \& Administration, 35(5), 559-568.

Hanna, A.K., \& Oh, P. (2000). Rethinking urban poverty: a look at community Gardens, Bulletin of Science. Technology \& Society, 20(3), 207-216.

Holland, L. (2004). Diversity and Connections in Community Gardens: A Contribution to Local Sustainability. Local Environment, 9(3), 285-305.

Howe, J., \& Wheeler, P. (1999). Urban food growing: The experience of two UK cities. Sustainable Development, 7(1), 13-24.

Lee-Smith, D. (2010). Cities Feeding People: An Update on Urban Agriculture in Equatorial Africa. Environment and Urbanization, 22(2), 483-499.

Martellozzo, F., Landry, JS., Plouffe, D. (2014). Urban agriculture: A global analysis of the space constraint to meet urban vegetable demand. Environmental Research Letters, 9(6), 25-64.

NCC (Ndola City Council). (2008). Key Issues and Recommendations on Urban Agriculture. Ndola: NCC.

Simatele, D., \& Binns, T. (2008). Motivation and Marginalisation in African Urban Agriculture: The Case of Lusaka, Zambia. Urban Forum, 19, 1-21.

Smith, J., Ratta, A., Nasr, J., Cheema, G. S. (1996). Urban agriculture: Food, jobs and sustainable cities. New York: United Nations Development Programme

Sznajder, M., Przezborska, M., \& Scrimgeor, F. (2009). «Agritourism», USA, CABI north American office.

Tuijl Erwin, V., Gert-Jan, H., Berg Leo., V. (2018). Opportunities and Challenges of Urban Agriculture for Sustainable City Development. European Spatial Research and Policy, Sciendo, 25(2), 5-22.

Viljoen, A., Bohn, K. \& Howe, J. (2015). Continuous productive urban landscapes: Designing urban agriculture for sustainable cities, Oxford: Architectural Press.

Walter, C., \& Dressler, M. (2013). Where to Grow? (Identifying Suitable Locations for Urban Agriculture in Federal Way, Washington), Forterra Organization.

Zahedi, S. (2007). Sustainable Development, Tehran: Samat Publishing, First Edition. 